http://jmscr.igmpublication.org/home/ ISSN (e)-2347-176x ISSN (p) 2455-0450

crossref DOI: https://dx.doi.org/10.18535/jmscr/v9i1.35

\title{
Haemoglobin Genotype Status awareness of Some Nursing Parents receiving Neonatal immunization in Jos, North-Central Nigeria
}

\author{
Authors \\ Iheanacho, Charity, U. (M.Sc) ${ }^{1}$, Ufelle, Silas, A. (Ph.D) ${ }^{2}$, Egbujo Ejike C. ${ }^{3}$, \\ Achukwu, Peter,U. (Ph.D) ${ }^{4}$ \\ ${ }^{1,2}$ Department of Medical Laboratory Sciences, Faculty of Medical and Health Sciences, University of \\ Nigeria, Enugu Campus \\ ${ }^{3}$ Meena Histopathology and Cytology Laboratory, No.1 constitution Hill rd. Jos Plateau State, Nigeria \\ ${ }^{4}$ Department of Medical Laboratory Sciences, Faculty of Medical and Health Sciences, University of \\ Nigeria, Enugu Campus
}

\begin{abstract}
Aims: To investigate the relationship of age, sex, education, occupation, tribe and geopolitical zones on haemoglobin genotype $(\mathrm{Hb})$ status awareness of Some Nursing Parents receiving Neonatal immunization in Jos, North-Central Nigeria.

Settings and Design: A quantitative, non-experimental descriptive study.

Method: A quantitative, non-experimental descriptive study involving 782 parents from Jos, North-central Nigeria nested in a Neonatal Haemoglobin Variants Screening Initiative (NHVSI) of infants receiving immunization.

Statistical Analysis Used: Data analysis was by use of Statistical Package for Social Sciences, version 23 (Chicago II, USA) software.

Result: A total of 782 participants were recruited comprising of 391 mothers and 391 fathers. Majority of the respondents did not know their status (57.8\%). Of the factors affecting their awareness sex had no significant difference. Age showed that respondents less than 20years of age, had the highest don't know status (82.6\%).Those with primary and non formal education had the highest don't know status (90\% and 86.7\%). Geopolitical zone northwest had the highest don't know (77.5\%) and the highest don't know for tribes was the Hausa-fulani (82.4\%).Lastly occupation showed that self-employed had the highest don't know.

Conclusion: This shows that more enlightenment campaign of Hb genotype and determined government drive to carry out a general Hb genotype screening of all citizens $\leq 20$ years of age is needed especially the Hausa/Fulani of the Northern part of Nigeria. Therefore Parental genotype screening should be included in neonatal screening program.
\end{abstract}

\section{Introduction}

Haemoglobinopathies or haemoglobin variant disorders (HVD) are the most common gene disorder worldwide with about seven percent of the world population being carriers of significant haemoglobinopathy. Despite the high burden of Sickle Cell Disease (SCD), Nigeria does not have a national newborn screening program for HVD ${ }^{[1]}$
For the development of a newborn screening program intended for the specific need of Nigerian health care, we aim at(a) determining the haemoglobin genotype status of some parents in north central Nigeria,(b) understand some factors that might be responsible for the pattern of haemoglobin genotype distribution, (c) its subsequent effect on neonatal screening. 


\section{Materials and Methods}

This cohort study was nested within the Neonatal Haemoglobin Variants Screening Initiative (NHVSI) of infants receiving immunization. It was a qualitative, non-experimental descriptive study of parents.

The age group was controlled for the intention of enrolling those apparently healthy, nonsymptomatic neonates for Haemoglobin variants screening using varying methods. To this, a preanalytical family history of the parents was first gathered to enable enrolment of their infants into the new born screening program according to the recommendation of ${ }^{[2-3]}$.

Three hundred and ninety one (391) mothers along with their male counterparts were recruited into this study. . Ethical clearance was obtained from the Jos University Teaching Hospital Ethical Committee (JUTH/DCS/ADM/127/XXVIII/1276) and validated in other research centres as required. The aims and objectives of the study were explained to the respondents verbally. A written consent was obtained from each participant before enrolment in the survey. All identifiers of the respondents were removed from the data collection tool to encourage the participants to give honest responses to them.

Health workers of the nursing and laboratory departments were recruited for the administration of consent forms and questionnaires. The infants' weights, temperature and general well being were checked by the $\mathrm{CHO}$ and paediatricians and subsequently sent for immunization if no health complications were observed while those with any questionable health issues were referred to the wards or given treatment by the Community Medicine Clinicians. On arrival for immunization of those within this age limit, consent forms were administered to the parents and those who completed the consent forms were issued questionnaires. This exercise took place in hospital based immunization centres from April, 2019 to July, 2019. This randomized sampling captured people from about thirty-two (32) states of the country dwelling in North-central Nigeria and it represented about $88.0 \%$ of the nation's thirty-six (36) states.

From the month of February, 2019 to April, 2019, an intern Medical Laboratory Scientist, Laboratory assistant and Community Health Officer that can speak English and Hausa were selected and trained on the administration and awareness talks of the $\mathrm{Hb}$ variants screening and its benefits as well as consent and questionnaire administration. The research principal investigator and the trained assistants conducted a crosssectional non-experimental study of the neonatal $\mathrm{Hb}$ variants, screening parents on their selfreported $\mathrm{Hb}$ genotype status, age, resident address, states of origin, occupation and educational status. The survey data were first piloted and validated in ten (10) hospital based parents in the course of the training. At the end of July, a total of seven hundred and eighty two (782) participants had been recruited. These formed the study population. Data analysis was by use of Statistical Package for Social Sciences, version 23 (Chicago II, USA) software. Data presentation was in form of tables and charts. Frequencies, proportions and percentages were calculated for categorical variables. Results of continuous variables were expressed as means standard deviation (SD) and medians. Chi-square analysis was used to test for association between categorical variables while student $\mathrm{t}$ - test was used to test significant relationship between parametric and nonparametric continuous variables respectively. Test of significance was set at $\mathrm{p}<0.5$.

\section{Results}

A total of 782 respondents completed the questionnaires and participated in this study. The study population comprised of 391 fathers (male) and 391 mothers (female). The modal age of the male was $31-40$ years $(52.9 \%)$ while the modal age of the female was $21-30$ years $(46.2 \%)$. The age range of the fathers is between $20-60$ years while that the mothers ranged from $18-51$ years. Majority of the study respondents had a form of tertiary education 445 (56.9\%). A good number of 
the respondents were either civil servants 231 $(29.5 \%)$ or business men and women 232 (29.7\%). The tribes of the respondents cut across major tribes in Nigerian with the Hausa/Fulani 336 (43.0\%) dominating, followed by Plateau local tribes $305(39.0 \%)$. All six geo political zones were represented in the study. (Table 1)

The respondents Haemoglobin (Hb) Genotype distribution shows that $75.8 \%$ were HbAA, $23.3 \%$ were $\mathrm{HbAS}, 0.9 \%$ were $\mathrm{HbSS}$ and Majority of the respondents $57.8 \%$ did not know their genotype(Table 2). Of the "Don't Know" class of respondents, $61.4 \%$ were males while $54.2 \%$ are females. At $\mathrm{P}<0.005$, there was a statistical difference of their knowledge gap between male and female as $\mathrm{P}=0.220$ (Table 3 ).

The age groups with least knowledge of their $(\mathrm{Hb})$ genotype were those of $\leq 20$ years accounting for $82.6 \%$ of their group while the most knowledgeable age group is $30-40(50.9 \%)$. There is a significance difference of their knowledge of $\mathrm{Hb}$ genotype in respect to age as the elder ones seem to know their $\mathrm{Hb}$ genotype more and $\mathrm{p}=$ 0.001 (Table 4).
A high percentage of those with primary education and non-formal education did not know their genotype $(90 \%$ and $86.7 \%)$ while respondents with tertiary education $59.3 \%$ know their genotype. The $(\mathrm{p}<0.005)$ of the knowledge and educational level attained is statistically significant different (Table 5).

The genotype knowledge when compared across tribes and geopolitical zones of respondents Table 6 and 7 showed a statistical significance ( $\mathrm{p}=0.001)$. The Hausa/Fulani were the highest that did not know their genotype (82.4\%). They occupy most of the North West and North Eastern zones which had the highest "Don't know" genotype status $(77.5 \%$ and $71.8 \%$ ) respectively [Table 6 and 7].

The relationship between respondents occupation and their knowledge of $\mathrm{Hb}$ genotype showed a statistical significance of $(p=0.001)$. The selfemployed and the business group had the highest "Don't know" status (73.8\% and 68.8\%). While the civil servants had the least "Don't know" status $(42.2 \%)$ [Table 8 ].

Table 1: Demographic characteristics of study participants

\begin{tabular}{|c|c|c|c|}
\hline \multirow[t]{2}{*}{ Demographic characteristics } & \multicolumn{3}{|c|}{ Gender } \\
\hline & $\begin{array}{c}\text { Male } \\
(\mathrm{n}=391)\end{array}$ & $\begin{array}{l}\text { Female } \\
(\mathrm{n}=391)\end{array}$ & $\begin{array}{c}\text { Total } \\
(\mathrm{n}=782)\end{array}$ \\
\hline \multicolumn{4}{|l|}{ Age group } \\
\hline$\leq 20$ & $37(9.5)$ & $32(8.2)$ & $69(8.8)$ \\
\hline $21-30$ & $34(8.7)$ & $195(49.9)$ & $229(29.3)$ \\
\hline $31-40$ & $207(52.9)$ & $154(39.4)$ & $361(46.2)$ \\
\hline $41-50$ & $96(24.6)$ & $9(2.3)$ & $105(13.4)$ \\
\hline$>50$ & $17(4.3)$ & $1(0.3)$ & $18(2.3)$ \\
\hline \multicolumn{4}{|l|}{ Educational level } \\
\hline None formal & $11(2.8)$ & $4(1.0)$ & $15(1.9)$ \\
\hline Primary & $22(5.6)$ & $28(7.2)$ & $50(6.4)$ \\
\hline Secondary & $112(28.6)$ & $160(40.9)$ & $272(34.8)$ \\
\hline Tertiary & $246(62.9)$ & $199(50.9)$ & $445(56.9)$ \\
\hline \multicolumn{4}{|l|}{ Occupation } \\
\hline Business & $148(37.9)$ & $83(21.2)$ & $231(29.5)$ \\
\hline Civil servant & $148(37.9)$ & $84(21.5)$ & $232(29.7)$ \\
\hline House wife & $0(0.0)$ & $119(30.4)$ & $119(15.2)$ \\
\hline Self-employed & $32(8.2)$ & $52(13.3)$ & $84(10.7)$ \\
\hline Student & $6(1.5)$ & $38(9.7)$ & $44(5.6)$ \\
\hline Unemployed & $10(2.6)$ & $7(1.8)$ & $17(2.2)$ \\
\hline Others & $47(12.0)$ & $8(2.0)$ & $55(7.0)$ \\
\hline \multicolumn{4}{|l|}{ Tribe } \\
\hline Hausa/Fulani & $167(42.7)$ & $169(43.2)$ & $336(43.0)$ \\
\hline Igbo & $14(3.6)$ & $15(3.8)$ & $29(3.7)$ \\
\hline Yoruba & $28(7.2)$ & $26(6.6)$ & $54(6.9)$ \\
\hline
\end{tabular}




\begin{tabular}{lccc}
\hline Plateau tribe & $151(38.6)$ & $154(39.4)$ & $305(39.0)$ \\
Others & $31(7.9)$ & $27(6.9)$ & $58(39.0)$ \\
Geo-political zone & & & \\
North Central & $273(69.8)$ & $271(69.3)$ & $544(69.6)$ \\
North East & $34(8.7)$ & $37(9.5)$ & $71(9.1)$ \\
North West & $41(10.5)$ & $39(10.0)$ & $80(10.2)$ \\
South West & $24(6.1)$ & $22(5.6)$ & $46(5.9)$ \\
South East & $14(3.6)$ & $13(3.3)$ & $27(3.5)$ \\
South South & $5(1.3)$ & $9(2.3)$ & $14(1.8)$ \\
\hline
\end{tabular}

Table 2: Self-reported Haemoglobin (Hb) genotype of study participants.

\begin{tabular}{lcc}
\hline Hb genotype & Frequency $(\mathrm{n}=782)$ & Percentage $(\%)$ \\
\hline Known & 330 & 42.2 \\
Don't know & 452 & 57.8 \\
& & \\
The knows $(\boldsymbol{n}=\mathbf{3 3 0})$ & & \\
HbAA & 250 & 75.8 \\
HbAS & 77 & 23.3 \\
HbSS & 3 & 0.9 \\
\hline
\end{tabular}

Table 3: Association between knowledge of genotype and gender of study participants

\begin{tabular}{lcccc}
\hline Gender & \multicolumn{2}{c}{$\begin{array}{c}\text { Knowledge of genotype } \\
\text { Known }\end{array}$} & $\begin{array}{c}\chi^{2} \\
\text { Don't know }\end{array}$ & P \\
\hline Male & $151(38.6)$ & $240(61.4)$ & 4.110 & 0.043 \\
Female & $179(45.8)$ & $212(54.2)$ & & \\
Total & $330(42.2)$ & $452(57.8)$ & & \\
\hline
\end{tabular}

Table 4: Association between knowledge of genotype and age of study participants

\begin{tabular}{lcccc}
\hline Age group & \multicolumn{2}{c}{$\begin{array}{l}\text { Knowledge of genotype } \\
\text { Known }\end{array}$} & $\begin{array}{c}\chi^{2} \\
\text { Don't know }\end{array}$ & $\mathrm{P}$ \\
\hline$\leq 20$ & $12(17.4)$ & $57(82.6)$ & 32.029 & 0.001 \\
$21-30$ & $91(39.7)$ & $138(60.3)$ & & \\
$31-40$ & $184(51.0)$ & $177(49.0)$ & & \\
$41-50$ & $37(35.2)$ & $68(64.8)$ & & \\
$>50$ & $6(33.3)$ & $12(66.7)$ & & \\
\hline
\end{tabular}

Table 5: Association between knowledge of genotype and educational level of study participants

\begin{tabular}{lcccc}
\hline Educational level & \multicolumn{2}{c}{ Knowledge of genotype } & $\chi^{2}$ & P \\
& Known & Don't know & & \\
\hline None formal & $2(13.3)$ & $13(86.7)$ & 126.791 & 0.001 \\
Primary & $5(10.0)$ & $45(90.0)$ & & \\
Secondary & $59(21.7)$ & $213(78.3)$ & & \\
Tertiary & $264(59.3)$ & $181(40.7)$ & & \\
\hline
\end{tabular}

Table 6: Association between knowledge of genotype and tribe of study participants

\begin{tabular}{lcccc}
\hline Tribe & \multicolumn{2}{c}{ Knowledge of genotype } & $\chi^{2}$ & P \\
& Known & Don't know & & \\
\hline Hausa/Fulani & $59(17.6)$ & $277(82.4)$ & 156.355 & 0.001 \\
Igbo & $25(86.2)$ & $4(13.8)$ & & \\
Yoruba & $33(61.1)$ & $21(38.9)$ & & \\
Plateau indigene & $183(60.0)$ & $122(40.0)$ & & \\
Others & $30(51.7)$ & $28(48.3)$ & & \\
\hline
\end{tabular}


Table 7: Association between knowledge of genotype and geo-political zone of study participants

\begin{tabular}{lcccc}
\hline Geo-political zone & \multicolumn{2}{c}{ Knowledge of genotype } & $\chi^{2}$ & P \\
& Known & Don't know & & \\
\hline North Central & $231(42.5)$ & $313(57.5)$ & 52.079 & 0.001 \\
North East & $20(28.2)$ & $51(71.8)$ & & \\
North West & $18(22.5)$ & $62(77.5)$ & & \\
South West & $29(63.0)$ & $17(37.0)$ & & \\
South East & $24(88.9)$ & $3(11.1)$ & & \\
South South & $8(57.1)$ & $6(42.9)$ & & \\
\hline
\end{tabular}

Table 8: Association between knowledge of genotype and occupation of study participants

\begin{tabular}{|c|c|c|c|c|}
\hline \multirow[t]{2}{*}{ Occupation } & \multicolumn{2}{|c|}{ Knowledge of genotype } & \multirow[t]{2}{*}{$\chi^{2}$} & \multirow[t]{2}{*}{$\mathrm{P}$} \\
\hline & Known & Don't know & & \\
\hline Business & $74(32.0)$ & $157(68.0)$ & 45.608 & 0.001 \\
\hline Civil servant & $134(57.8)$ & $98(42.2)$ & & \\
\hline House wife & $52(43.7)$ & $67(56.3)$ & & \\
\hline Self-employed & $22(26.2)$ & $62(73.8)$ & & \\
\hline Student & $23(52.3)$ & $21(47.7)$ & & \\
\hline Unemployed & $7(41.2)$ & $10(58.8)$ & & \\
\hline Others & $18(32.7)$ & $37(67.3)$ & & \\
\hline
\end{tabular}

\section{Discussion}

Early awareness and correct knowledge of one's $\mathrm{Hb}$ genotype could provide information that will guide decisions of potential marriage partners. This guided marriage choice will lead to reduced $\mathrm{Hb}$ variants carriers, child morbidity, mortality and improved national health burden; ${ }^{[4]}$. Although, no specific time has been identified for individuals self, correct-knowledge of $\mathrm{Hb}$ genotype but some opined that it be before marriage ${ }^{[5,6 \& 7]}$. However, ${ }^{[1 \& 2]}$ were of the opinion that neonatal screening and documentation be employed for early awareness. This second opinion will aid in eradicating to a great extent the $\mathrm{Hb}$ variants disorders as some countries have almost achieved $^{[8]}$.

In the quest to determine the $\mathrm{Hb}$ genotype awareness status of parents in the north central Nigeria, general demographic information of the respondents was noted as above (Table 1). The age range of the respondents was 20-60 years (men) and 18-51years (women). This was slightly different from the report of ${ }^{[9]}$, whose child bearing age of their study population or fertility age was 30-49(men) and 18-49(women), but was however in agreement with works of ${ }^{[10]}$ whose respondents age were $(<21->61$ years) for both male and female. Very few respondents in our study had no formal education (1.9\%) while majority had some level of formal education with those having tertiary education having the highest percentage $(56.9 \%)$. This was contrary to the findings of ${ }^{[11]}$, who had $7 \%$ tertiary education for the North-central zone. This might be explained by the rural setting study design of their study in contrast to our own urban setting design. However, it agreed with the findings of ${ }^{[12-13]}$ whose tertiary educational status of the respondents parents are (39-42\% female and 52$54.4 \%$ male) and (70.4\% male and $58.3 \%$ female) respectively. Majority of respondents are gainfully employed either civil servants $(29.7 \%)$ or business owners $(29.5 \%)$ with only $2.2 \%$ being unemployed. The tribes of the respondents cut across the major tribes in Nigerian, with the Hausa/ Fulani rating highest (43\%) while the Igbo were the least with $3.7 \%$ (Table 1). This was in keeping with the works of ${ }^{[14]}$ were they had $78.1 \%$ and $6.7 \%$ for Hausa/Fulani and Igbo respectively. The higher rating of the Hausa/Fulani could be due to the fact that their work was done in Sokoto; (North-Western Nigeria) that is mainly dominated by the Hausa/Fulani. Similarly this present work was in the North-Central Nigeria that also has a high population of Hausa/Fulani though not as high as North-Western Nigeria. In as much as this work was done in North-central Nigeria, the 
respondents' origins cut across the six geopolitical zones of Nigeria (Table 1).

Table 2, shows the self-reported $\mathrm{Hb}$ genotype of child-bearing mothers and their spouses. Majority of the respondents did not know their $\mathrm{Hb}$ genotype (57.8\% "Don't Knows"), while only $42.2 \%$ claimed to know their $\mathrm{Hb}$ genotype (42.2\% "Knows"). The self-reported genotypes of those that claim to know their $\mathrm{Hb}$ genotype are as follows: AA-75.8\%, AS-23.3\% and SS-0.9\% respectively. Our findings were similar to those of ${ }^{[15]}$ (AA- 59.2\%, AS- $11.1 \%$ and $40.8 \%$ don't know) also in agreement with ${ }^{[16]}$ whose subjects had $19.2 \%$ misreported or misidentified genotype and $45 \%$ don't know cases while ${ }^{[17]}$ had $36.2 \%$ don't know, 54\% AA, 7.3\% AS and $2.5 \%$ SS. These previous works captures results from the North-central and South-central zones. This knowledge gap of misreported, misidentified or unknown $\mathrm{Hb}$ genotype subsequently endangers the process of the fight against SCD and /or HVD in Nigeria. To overcome this knowledge gap the study seeks to find the relationships or association of reported $\mathrm{Hb}$ genotype to gender, age, educational level, tribe, geopolitical zone and occupation of the respondents.

Table 3 shows the association between knowledge of $\mathrm{Hb}$ genotype and gender. There was no statistical significant difference between male and female in relation to $\mathrm{Hb}$ genotype $\mathrm{P}<0.005$. This shows that the knowledge gap was not sex dependant as evident from the results. This implies that being male or female does not give one the ability to know his/her genotype.

For the association of $\mathrm{Hb}$ genotype knowledge and the age groups of the respondent, there was a significant difference (table 4). Those with lower age limit of less than 20years of age had the highest "don't know" status and the middle age of 31-40 years had the least "don't know" status. The lower age group will possibly be representing the non-educated group or those with primary level educational status in this study as well as the unemployed respondents. The findings of other scholars in Nigeria like ${ }^{[12,15,18, \& 19]}$ suggested that the middle aged group had better knowledge of $\mathrm{Hb}$ genotype than their younger counterparts. A probable explanation to this might be the rout of awareness of these respondents. . According

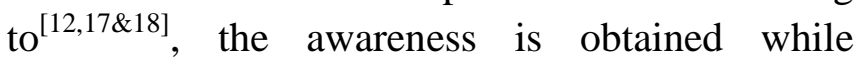
seeking admission into post primary school, higher institution, through media, during marriage, at work place or while seeking for job. It is obvious that most of this middle aged group had the indices of literacy and age maturity at their advantage. This implies that infants of younger and illiterate parents are at higher risk of being diagnosed only after manifestation of symptoms which increases their morbidity and mortality rate and increased health burden on the nation.

Education was another factor considered in respect to the knowledge of their $\mathrm{Hb}$ genotype and a significant difference was observed (table 5). The primary and non-formal educated respondents had the highest "don't know" status $(90.0 \%$ and $86.7 \%$ respectively) and the tertiary education group had the least "don't know" status (40.7\%). These findings were in agreement with the works of ${ }^{[14 \& 25]}$, and just like age, can be explained by the mode of awareness. It is evident that a definite effort should be made by the government \& NGOs to encourage education and make it appealing to the region of the North-central Nigeria.

The association between the knowledge of $\mathrm{Hb}$ genotype to tribe and geo-political zone seem to be intertwined. They both showed a statistically significant difference (table 6 and 7). Hausa/Fulani had the highest don't know (82.4\%) and Igbo with the least don't know (4\%). Similarly North West, North East and North Central have the highest don't know status (77.5\%, 71.8\% and 57.5\% respectively). Cultures that forbid female education and promote child marriages are common in Northern Nigeria where the Hausa/Fulani inhabit. Also, the practice of traditional medicines and less of hospital based anti-natal care with treatment also reduces their chances of knowledge of $\mathrm{Hb}$ genotype ${ }^{[20]}$. The tribe and geo-political location of the participants seem to affect their ability to know or have 
awareness of their $\mathrm{Hb}$ genotype. This inference is from the fact that in our study, $82.4 \%$ of the Hausa/Fulani did not know their genotype and they occupied mainly the north-west and northeastern zone of the country and they had $77.5 \%$ and $71.8 \%$ "don't know" rate which were the highest in the study group. This work is also in agreement with work of Isa from Sokoto ${ }^{[14]}$, the north western Nigeria were $65.9 \%$ of their population did not have a good knowledge of SCD. Studies have shown that this group has the lowest educational level, highest girl-child marriage and more frequent old man to girl child marriage $^{[20]}$.

Finally, the association between knowledge of $\mathrm{Hb}$ genotype and occupation was statistically significant (table 8) showing self-employed having the highest don't know (73.8\%) and civil servants with the least don't know (42.2\%). These results are similar to those of age and education. The least don't know (civil servants) class of individuals fit into the middle-aged group, educated and have access to all forms of media and information technology. However, the highest don't know (self-employed) represent more of those with less formal educational class and uneducated group, lower class of the society that lacks access or understanding for the various means of genotype awareness. They mostly prefer herbal treatments and patronize traditional birth care givers private where most routine procedures are not usually followed or rather they rely on patients' reported parameters. These are in tandem with the postulated awareness pattern of ${ }^{[12 \& 17]}$.

\section{References}

1. Burnham-Marusich, A. R., Ezeanolue, C. O., Obiefune, M. C., Yang, W., Osuji, A., Ogidi, A. G., ... \& Ezeanolue, E. E. (2016). Prevalence of sickle cell trait and reliability of self-reported status among expectant parents in Nigeria: implications for targeted newborn screening. Public Health Genomics, 19(5), 298-306.
2. Ryan, K., Bain, B., Worthington, D., James, J., Plews, D., Mason, A., ... \& Streetly, A. (2010). Significant haemoglobinopathies: guidelines for screening and diagnosis. British journal of haematology, 149(1), 35-49.

3. Kotila, T. R. (2010). Guidelines for teh diagnosis of the haemoglobinopathies in Nigeria. Annals of Ibadan postgraduate medicine, 8(1), 25-29.

4. Piel, F. B., Howes, R. E., Patil, A. P., Nyangiri, O. A., Gething, P. W., Bhatt, S., ... \& Hay, S. I. (2013). The distribution of haemoglobin $\mathrm{C}$ and its prevalence in newborns in Africa. Scientific reports, 3(1), 1-8.

5. Ezechukwu, C. C., \& Chukwuka, J. O. (2004). Pre-marriage counseling as a tool for sickle cell disease awareness in Nigerians. Sahel Medical Journal,7(2), 54.

6. Nnaji, G. A., Ezeagwuna, D. A., Nnaji, I. J. F., Osakwe, J. O., Nwigwe, A. C., \& Onwurah, O. W. (2013). Prevalence and pattern of sickle cell disease in premarital couples in Southeastern Nigeria. Nigerian journal of clinical practice, 16(3), 309314.

7. Taiwo, I. A., Oloyede, O. A., \& Dosumu, A. O. (2011). Frequency of sickle cell genotype among the Yorubas in Lagos: implications for the level of awareness and genetic counseling for sickle cell disease in Nigeria. Journal of community genetics, 2(1), 13-18.

8. Weatherall, D. (2011). The inherited disorders of haemoglobin: an increasingly neglected global health burden. The Indian journal

9. Amoo, E. O. (2017). Trends and determinants of female age at first marriage in Sub-Sharan Africa (19902014) What has changed?. African Population Studies, 31(1), 3573-3585. 
10. Nnodu, O. E., Adegoke, S. A., Ezenwosu, O. U., Emodi, I. I., Ugwu, N. I., Ohiaeri, C. N., ... \& Bene, B. A. (2018). A Multicentre Survey of Acceptability of Newborn Screening for Sickle Cell Disease in Nigeria. Cureus, 10(3).

11. Azad, M., Crawford, E. E., \& Kaila, H. K. (2018). Conflict and Violence in Nigeria: Results from the North East, North Central, and South South Zones (No. 130198, pp. 1-44). The World Bank.

12. Babalola, O. A., Chen, C. S., Brown, B. J., Cursio, J. F., Falusi, A. G., \& Olopade, O. I. (2019). Knowledge and health beliefs assessment of sickle cell disease as a prelude to neonatal screening in Ibadan, Nigeria. Journal of Global Health Reports, 3.

13. Ameen, H. A., Abidoye, A. K., AlatisheMuhammad, B. W., Aderibigbe, S. A., Uthman, M. M. B., Bolarinwa, O. A., ... \& Akande, T. M. (2016). Prevalence of heamoglobin genotype screening and awareness of SCD among undergraduate students of Unilorin. Journal of Medicine and Biomedical Research, 15(1), 14-27.

14. Isah, B. A., Musa, Y., Mohammed, U. K., Ibrahim, M. T. O., Awosan, K. J., \& Yunusa, E. U. (2016). Knowledge and attitude regarding premarital screening for sickle cell disease among students of state school of nursing Sokoto. Annals of International Medical and Dental Research, 2(3), 29-34.

15. Olakunle, O. S., Kenneth, E., Olakekan, A. W., \& Adenike, O. B. (2013). Knowledge and attitude of secondary school students in Jos, Nigeria on sickle cell disease. Pan African Medical Journal, 15(1).
16. Aderotoye-Oni, S., Diaku-Akinwumi, I. N., Adeniran, A., \& Falase, B. (2018). Unprepared and misinformed parents of children with sickle cell disease: time to rethink awareness campaigns. Cureus, 10(12).

17. Faremi, A. F., Olatubi, I. M., \& Lawal, Y. R. (2018). Knowledge of Sickle Cell Disease and Pre Marital Genotype Screening among Students of a Tertiary Educational Institution in South Western Nigeria. International Journal of Caring Sciences, 11(1), 285-295.

18. Chukwu, B. F., Ezenwosu, O. U., Eke, C. B., Chinawa, J. M., Ikefuna, A. N., \& Emodi, I. J. (2014). What factors influence the age at diagnosis of sickle cell anemia in Enugu, Nigeria. $J$ Blood Disord Transf, 5, 233.

19. Ezenwosu, O. U., Chukwu, B. F., Ikefuna, A. N., Hunt, A. T., Keane, J., Emodi, I. J., \& Ezeanolue, E. E. (2015). Knowledge and awareness of personal sickle cell genotype among parents of children with sickle cell disease in southeast Nigeria. Journal of community genetics, 6(4), 369-374.

20. Para-Mallam, O. J. (2012). Transforming education for girls in Nigeria and Tanzania: Nigeria endline research report. 